\title{
of protein sources in the starter ration on the behavioural response of suckling buffalo calves
}

\author{
ARUN KUMAR, D.N. SINGH AND R.S. YADAV
}

\begin{abstract}
The experiment was conducted on 18 buffalo calves of about 1-3 months of age to find effects of three different calf starters (differing on the source of protein) on the behavioural response and cost of rearing. The calves were divided into three groups (six calves in each group) randomly under three treatments i.e. $\mathrm{T}_{1}, \mathrm{~T}_{2}$ and $\mathrm{T}_{3}$. In $\mathrm{T}_{1}$ group groundnut cake, $\mathrm{T}_{2}$ group soyabean and in $\mathrm{T}_{3}$ group mustard cake with fish meal $(10 \%)$ as protein source, respectively with green fodder and bhusa was fed ad lib. Average eating time spent during day time by the calves were $215.53 \pm 8.703,213.16 \pm 9.841$ and $182.03 \pm 10.318$ minutes and the corresponding figures for rumination and resting time spent during day time were $130.07 \pm 5.397,168.17 \pm 6.742$ and $152.0 \pm$ 11.475 minutes and $280.57 \pm 14.988,274.77 \pm 18.566$ and $226.03 \pm 18.540$ minutes in $\mathrm{T}_{1}, \mathrm{~T}_{2}$ and $\mathrm{T}_{3}$ groups, respectively revealed that feeding behaviour was significantly influenced by the treatments. The eating time was significantly $(\mathrm{P}<0.05)$ low in $\mathrm{T}_{3}$ as compared to $T_{1}$ and $T_{2}$. However, there was no significant difference between $T_{1}$ and $T_{2}$. The rumination time was significantly $(P<0.05)$ higher in $\mathrm{T}_{2}$ as compared to $\mathrm{T}_{3}$. The rearing cost per kg body weight gain was Rs. 33.86, 26.91 and 32.56 in $\mathrm{T}_{1}, \mathrm{~T}_{2}$ and $\mathrm{T}_{3}$, respectively. The cost per kg body weight gain was less in $\mathrm{T}_{2}$ followed by $\mathrm{T}_{1}$ and $\mathrm{T}_{3}$.
\end{abstract}

KEY WORDS : Behaviour, Calf starter, Feed conversion efficiency, Rearing cost

HOW TO CITE THIS PAPER : Kumar, Arun, Singh, D.N. and Yadav, R.S. (2015). Effect of protein sources in the starter ration on the behavioural response of suckling buffalo calves. Res. J. Animal Hus. \& Dairy Sci., 6(1) : 41-43.

Address for correspondence :

D.N. Singh, College of Veterinary Science and Animal Husbandry, Pt. Deen Dayal Upadhyaya Pashu Chikitsa Vigyan Vishwavidyalaya Evam Go-Anusandhan Sansthan, MATHURA (U.P.) INDIA

Email : drdeep25@gmail.com

Associated Authors' :

Arun Kumar, Panchmahal District Co-operative Milk Producers Union Ltd., (GUJARAT) INDIA

Email : kumararun80@ rediffmail.com

R.S. Yadav, Chaudhary Charan Singh Haryana Agricultural University, HISAR (HARYANA) INDIA 